\title{
IFNL2 wt Allele
}

National Cancer Institute

\section{Source}

National Cancer Institute. IFNL2 wt Allele. NCI Thesaurus. Code C104348.

Human IFNL2 wild-type allele is located in the vicinity of $19 q 13.13$ and is approximately 2 $\mathrm{kb}$ in length. This allele, which encodes interferon lambda-2 protein, plays a role in both the response to viral infection and cytokine signaling. 